\title{
Strategic Vision And Mission Practices On Service Delivery In Rwanda Development Board
}

\author{
Gahonzire, Y. ${ }^{1}$, Mulyungi, M. P. ${ }^{2}$ \\ 1. Jomo Kenyatta University of Agriculture and Technology \\ 2. Jomo Kenyatta University of Agriculture and Technology \\ DOI: 10.29322/IJSRP.10.11.2020.p10764 \\ http://dx.doi.org/10.29322/IJSRP.10.11.2020.p10764
}

\begin{abstract}
Over the past decade strategic vision and mission practices are important to the strategic plan implementation of any organization specifically in public sector where it comes to service delivery. Public organizations in Rwanda spends much time and effort on their formulation as they aren't used as planning instruments. The purpose of the study was to examine the influence of strategic vision \& mission practices on service delivery in Rwanda Development Board. This study adopted a descriptive approach. The study target population was 114 employees from Rwanda development Board. A sample of 89 respondents was determined using Slovin's formula which was stratified into three strata: top management staff, middle management staff, and low-level management staff. Census method brought out the aspect of accuracy and reliability to this study, because, each and every individual participated to this study. The study findings indicated that the coefficient of Strategic vision \& mission practices was 0.099 which was greater than zero. The $t$ statistic of this coefficient is 2.124 with a p value of 0.034 which is less than 0.05 . This implies that the coefficient 0.099 is significant. Since the coefficient is significant, it shows that Strategic vision \& mission practices making has a significant influence on service delivery at Rwanda Development Board. The study concludes that employee skill development, mentorship, delegation and motivation should be embraced for enhanced service delivery. The study recommends that the Rwanda Development Board should partner with training consultancy organizations such as universities to equip employees with relevant skills by conducting periodical needs assessment.
\end{abstract}

Index Terms- Strategic vision and mission practices, Service delivery, Rwanda Development Board

\section{BACKGROUND OF THE STUDY}

$S^{-1}$ trategy implementation involves both operationalization and Sinstitutionalization of strategy. Operationalization is concerned with turning strategic intent into operational reality. Boggis and Trafford (2014) argue that there is often more to operationalizing strategy than making structural changes, redesigning processes and training staff. They assert that for strategies to be truly successful, leaders need to create the conditions that enable the organization to pull itself into an improved future, a future that not only reflects the strategic intent, but also becomes operational reality. For this to happen, institutionalization must occur.
According Daft (2010) concept on strategy implementation has continued to evolve in competitive organization. A number of factors that have been pointed out by acknowledged scholars like Thompson, Gamble and Strickland (2012) which determine strategy implementation in an organization are employee development, leadership and structure. Development of employee skills and knowledge through trainings can promote creativity and the flexibility of implementation new policies or plans formulated. Delegation and job appraisal among workers can enable the organization identify key competencies among workers that can lead to strategy implementation thus firm performance (Efendioglu \& Karabulut, 2010). John and Richard (2011) argues that leadership and strategy implementation are directly correlated in organization context. Visionary leaders are always keen on creating a platform that will promote team spirit in an organization thus strategy implementation (Konzi, 2012). The ability of leaders to formulate policies that will promote synergy among workers and drive them to work towards organization goals is the fundamental aspect of any successful organization. In addition, organizations that continuously review their operational structures are more likely to enhance efficiency and effectiveness in service delivery. Organizations with organic structures and more likely to implement strategies more effectively compared to organizations with mechanistic structures (Kinyanjui \& Juma, 2014).

Building on the investment law of 2006, the GOR established Rwanda development board (RDB) in 2008 to fast track development projects and to facilitate new investment. RDB consolidates several Agencies previously involved in promoting investment including the Rwanda investment and export promotion Agency, the Rwanda commercial registration service Agency, the human and institutional capacity development Agency, the Rwanda information and technology agency, and the Rwanda office of tourism and national parks (Affairs, bureau of economic and business development report, 2012)

In this regard, governments realized RDB as a critical and strategic tool with potential to provide efficient and effective services and generally improve government operations (Bizimana, 2012). Consequently, the government of Rwanda embraced began anticipation on increasing efficiency, effectiveness, transparency, simplify procedures, improve record management, reduce corruption and enhance attitudinal change. Further, RDB aims at shifting from the silo mentality, bureaucratic, and paper-based transactional approach towards electronically propelled systems to develop participation, accountability, transparency and accessibility. Its against this background that the study will 
investigate the influence of strategic plan implementation practices on service delivery in public sector in Rwanda: a case of Rwanda Development Board.

\section{STATEMENT OF THE PROBLEM}

Over the years the government of Rwanda has experienced notable growth. However, this growth has not been accompanied by development of efficient systems to ensure that the sector plays its role in an efficient manner. The government introduced Irembo a portal that ensures public service delivery however public service delivery has been plagued by lack of accountability, transparency, corruption, archaic systems, poor working conditions, and often insensitive services that lead to inefficiency, rigidity, ineffectiveness, dissatisfaction and general underperformance. In addition, the online registration of companies carried by Rwanda development Board has been having a lot of questions in terms of service delivery since even after registering a company online one has to physically take documents for verification.

Even though numerous studies have conducted locally concerning the effect of strategy implementation practices and organization performance, it is noted that little attention has been paid by previous researchers in this area thus inconclusive findings resulting to conceptual and contextual gaps. This study therefore will seek to determine the influence of strategic mission and vision practices on service delivery in public sector in Rwanda: a case of Rwanda Development Board. Hence, the need to fill these gaps.

\section{LITERATURE REVIEW}

\section{Human Capital Theory}

Human Capital Theory (HCP) was advanced by Theodore Shutz and Gary Becker in the early 1960's. It state that investment in staff training increases an individual 's skills and abilities obtained can potentially increase productivity and performance of individuals 'work. Human Capital represents the combined intelligence, skills and expertise that give the organization its distinctive character (Wolfgang, 2010). Research findings by Zahid and Khan (2011) highlights that the human elements of the organizations are those that are capable of learning, changing, innovating and providing the creative thrust which if properly motivated can ensure that long term survival of the organizations. The theory distinguishes firm-specific human capitals from general-purpose human capital. Examples of firm-specific human capital include expertise obtained through education and training in management information systems, accounting procedures, or other expertise specific to a particular firm. General-purpose human capital is knowledge gained through education and training in areas of value to a variety of firms such as generic skills in human resource development (Onyango, 2012). In practice fulltime education is, too readily, taken as the principal example. For workers, investment in human capital involves both direct costs, and costs in foregone earnings (Odongo, Owuor, 2015). Despite the important role of human capital in modern societies, there are still many unknowns about the process of educational production as well as individual and collective decisions concerning how much and what kind of education to obtain.
The theory applicable in this study on the premise that employee skills and knowledge led to quality decisions formulation and implementation to promote organizational performance. Organizations should invest in employee trainings in order implement strategies formulated without difficult. Employee training will minimize change resistance and enhance strategic planning process. Hence the employees will have strategic vision and mission practices towards service delivery in Rwanda Development Board.

\section{STRATEGIC VISION AND MISSION PRACTICES}

A vision statement is a company's road map, indicating both what the company wants to become and guiding transformational initiatives by setting a defined direction for the company's growth. Vision statements undergo minimal revisions during the life of a business, unlike operational goals which may be updated from year-to-year. Vision statements can range in length from short sentences to multiple pages. Vision statements are also formally written and referenced in company documents rather than, for example, general principles informally articulated by senior management. The creation of a broad statement about the company's values, purpose, and future direction is the first step in the strategic-planning process. The vision statement must express the company's core ideologies — what it stands for and why it exists - and its vision for the future, that is, what it aspires to be, achieve, or create. Commonly cited traits of a good vision include; concise, clear, future oriented, stable, challenging, abstract and inspiring. Vision statements serve as foundations for a broader strategic plan, motivate existing employees and attract potential employees, help company focus and facilitate the creation of core competencies and help companies differentiate (Darbi, \& Phanuel, 2012).

\section{CONCEPTUAL FRAMEWORK}

A conceptual framework is a scheme of concepts or variables which the researcher operationalizes in order to achieve set objectives. It is a schematic or diagrammatic presentation of the theory. The theory is presented as a model where research variables and the relationship between them are translated into a visual picture to illustrate the interconnections between the independent and dependent variables (Oso \& Onen2009). It was derived from the Human Capital theory (Wolfgang, 2010). The independent variable is strategic vision \& mission practices, while the dependent variable is service delivery.

The relationship between the independent variables and the depended variable was established by the regression model and the conceptual frame work of the study as shown in Figure 1. 


\section{Independent variable Dependent variable}

\begin{tabular}{|c|c|}
\hline $\begin{array}{l}\text { Strategic vision \& } \\
\text { mission practices } \\
\text { - } \quad \text { Needs Assessment } \\
\text { - } \quad \text { Professional } \\
\quad \text { Development }\end{array}$ & \begin{tabular}{cl}
\multicolumn{2}{l}{ Service Delivery } \\
$\bullet$ & Quality \\
- & Customer \\
& satisfaction
\end{tabular} \\
\hline
\end{tabular}

Figure 1: Conceptual framework

\section{RESEARCH METHODOLOGY}

The study utilized the descriptive survey design. The population of this study consisted of management team, middle management level managers and low-level managers of Rwanda Development Board who in total were 114 respondents. A total of 89 employees constituted the sample size for this study. This study used stratified method to put the entire population into Six strata. These are Managers, Marketing team, Operations, Finance, Customer care and Human Resource. The researcher used both open-ended and close-ended questionnaires. These are set of questions designed to extract information relating to a survey. In this study reliability was ensured through a piloted questionnaire that was subjected to a sample of 10 staff members that were not included in the study. The 10 staff members were selected from MINECOFIN. The pre-test was conducted using Cronbach's Alpha coefficient reliability. The researcher analyzed data using Statistical Package for Social Science (SPSS) summarize it by use of frequencies, distribution tables, and percentage. The representation of data was done by use of pie charts, bar graphs and frequency tables that helped the researcher to arrive at a descriptively meaningful analysis of the results.

\section{RESULTS AND FINDINGS}

\section{Strategic vision \& mission practices}

Based on research objective two, the study examined the influence of strategic vision \& mission practices on service delivery in Rwanda Development Board. Respondents opinion was based on a five-point Likert scale where respondents were supposed to indicate the level of agreement with different statements regarding statements on strategic vision \& mission practices. The study used a Likert scale of $1-5$, where $1=$ No extent; $2=$ Little extent; $3=$ Some extent; $4=$ Great extent; 5 = Very great extent. The analysis is as shown in Table 1

Results in Table 4.10 reveal that majority of the respondent $94.2 \%$ agreed that the top management ensures quality objectives are established. $82.6 \%$ of the respondents agreed that At RDB there is Institutionalization of Corporate Vision while $89.5 \%$ of the respondents agreed that over the past year RDBs programs and projects met its goals. Lastly, $83.7 \%$ strongly agreed that vision and mission statement are used to guide RDB decisions and choice of activities.

The study agrees with Darbi and Phanuel (2012) commonly cited traits of a good vision include; concise, clear, future oriented, stable, challenging, abstract and inspiring. Vision statements serve as foundations for a broader strategic plan, motivate existing employees and attract potential employees, help company focus and facilitate the creation of core competencies and help companies differentiate.

Table 1: Descriptive analysis results for strategic vision \& mission practices

\begin{tabular}{|c|c|c|c|c|c|c|c|}
\hline Statements & 1 & 2 & 3 & 4 & 5 & Mean & Std. \\
\hline $\begin{array}{lr}\text { The } & \text { top } \\
\text { management } & \\
\text { ensures } & \text { quality } \\
\text { objectives } & \text { are } \\
\text { established } & \end{array}$ & 0.0 & 3.5 & 2.3 & 61.6 & 32.6 & 4.23 & 0.66 \\
\hline $\begin{array}{l}\text { At RDB there is } \\
\text { Institutionalization } \\
\text { of Corporate } \\
\text { Vision }\end{array}$ & 0.0 & 0.0 & 17.4 & 53.5 & 29.1 & 4.12 & 0.67 \\
\hline $\begin{array}{l}\text { Over the past year } \\
\text { RDBs programs } \\
\text { and projects met } \\
\text { its goals. }\end{array}$ & 0.0 & 2.3 & 8.1 & 43.0 & 46.5 & 4.34 & 0.73 \\
\hline $\begin{array}{l}\text { The vision and } \\
\text { mission statement } \\
\text { are used to guide } \\
\text { RDB decisions } \\
\text { and choice of } \\
\text { activities. }\end{array}$ & 0.0 & 0.0 & 16.3 & 58.1 & 25.6 & 4.09 & 0.64 \\
\hline
\end{tabular}

Correlation between strategic vison and mission practices and service delivery

This publication is licensed under Creative Commons Attribution CC BY. 
Correlation analysis was conducted to empirically determine whether strategic vision \& mission practices had a significant effect on service delivery in Rwanda Development Board. Results indicates that strategic vision \& mission practices are significantly correlated to service delivery in Rwanda Development Board $(\mathrm{r}=0.734, \mathrm{p}=.000)$.

Table 2: Correlation between strategic vison and mission practices and service delivery

Strategic vision $\&$ mission practices Service delivery

\begin{tabular}{llll}
\hline Strategic vision \& mission practices & Pearson Correlation & 1 \\
& Sig. (2-tailed) & .000 & \\
Service delivery & Pearson Correlation & $.734^{* *}$ & 1 \\
& Sig. (2-tailed) & .000 & \\
\hline
\end{tabular}

**. Correlation is significant at the 0.01 level (2-tailed).

\section{DISCUSSION OF RESULTS}

The study findings agree with Cornelissen (2014) who used a stakeholder-values perspective to explain mission: "A mission is a general expression of the overriding purpose of the organization, which, ideally, is in line with the values and expectations of major stakeholders and concerned with the scope and boundaries of the organization.

In this illustration, Organization A would prioritize cost efficiency, routinization, building upon the patents of others, and creating a reliable product with much consumer value built in. It would likely be a mid-to-late market entrant working on crops that are in steady demand. Conversely, Organization B would spend a great deal more time and resources on the laboratory science needed to alter specific crops and would be considered a market pioneer with a unique and more expensive product. Additionally, the core ethical values built into Organization A (value, reliability, output) stand in contrast with the core ethical values of Organization B (experimentation, innovation, leadership). Incentive structures in each organization would be different and employees would experience greater rewards by working in concert with organizational values (Bowen, 2015). This example illustrates how even a simple mission statement can change the overall priorities and operations of an organization.

\section{CONCLUSION}

The findings of the study indicated that Strategic communication practices, Strategic vision \& mission practices, Strategic organizational cultural practices and Strategic leadership practices were key driver of service delivery at Rwanda Development Board and the study concludes that employee skill development, mentorship, delegation and motivation should be embraced for enhanced service delivery.

\section{RECOMMENDATIONS}

The study established that Strategic leadership practices was attributed to organization service delivery even though to a larger extent some leadership practices were not embraced. Therefore, this study recommends that the Rwanda Development Board through the MIFOTRA should ensure that leaders appointed to top leadership positions are recruited on the basis of experience, knowledge and skills to drive the institutions to realize the longterm goals. Top leaders should ensure they embrace best leadership practices such as participatory leadership and accountability. The study found out that even though communication influenced service delivery, to a larger extent structures adopted discouraged two-way communication. Therefore, this study recommends that the Rwanda Development Board through the MIFOTRA should review the organization structure and adopt a more efficient and effective structures that encourage two-way communication approach for effective strategy implementation and service delivery.

\section{AREAS OF FURTHER RESEARCH}

Further research could be undertaken to assess the effect of strategic planning on employee satisfaction in public sector in Rwanda.

\section{REFERENCES}

[1] Ahmadi, S, A., Salamzadeh, Y., Daraei, M., \& Akbari, J. (2012). Relationship between Organizational Culture and Strategy Implementation: Typologies and Dimensions. Global Business and Management Research: An International Journal, 4(3-4), 286-299.

[2] Aldehayyat, J. S., \& Al Khattab, A. A. (2013). Strategic planning and organizational effectiveness in Jordanian hotels. International Journal of Business and Management, 8(1), 11-25. Doi:10.5539/ijbm.v8n1p11

[3] Arshida, M. M., \& Agil, S. O. (2012). Critical Success Factors for Total Quality

[4] Management Implementation within the Libyan Iron and Steel Company. Libyan: Tun Abdul Razak University.

[5] Babbie, E, R. (2010). The Practice of Social Research. (12th ed.), Belmont, CA W: adsworth Cengage

[6] Bizimana J.C. (2012). Contribution of foreign direct investment on socioeconomic Development. Case study of GASABO District, Rwanda. Kigali: INILAK

[7] Boggis, P., \& Trafford, D. (2014). Operationalizing Strategy-Turning Strategic Intent into Operational Reality. Formicio Limited

[8] Bosse, D.A. and Harrison, J.S. (2011). Stakeholders, entrepreneurial rent and bounded self-interest. In R.A. Phillips, Ed. Stakeholder, Theory: Impact and Prospects, Cheltenham, (4), 193-211 
[9] Cania L. (2014). Impact of Strategic Human Resource Management on Organizational Performance. Retrieved from: http://management.ase.ro/reveconomia/2014- 2/14.pdf

[10] Catalin, S. B., \& Dimitrie, G. R. (2014). The Existing Barriers in Implementing Total Quality Management. Annals of the University of Oradea, Economic Science Series, 23(1), 1234-1240.

[11] Cater, T., \& Pucko, D. (2010). Factors of effective strategy implementation: Empirical evidence from Slovenian business practice. Journal for East European Management Studies, 15(3), 207-236.

[12] Churchill, G (2012). Marketing Research Methodological Foundations. (9th ed.). Mason: South-Western Thomson. Jersey: Wiley.

[13] Cooper, D. \& Schindler, P. (2011). Business research method (8th ed.). New Delhi:Ta McGraw Hill.

[14] Cooper, D. R., \& Schindler, P. S. (2013). Business Research Methods. New York: McGraw-Hill/Irwin.

[15] Daft, R. L. (2010). New era of management (9th ed.) South-Western College, Cengage Learning.

[16] Daft, R. L., \& Marcic, D. (2013). Management: the new workplace. Australia: Southwestern, Cengage Learning.

[17] Darbi, K. \& Phanuel, W. (2012). "Of Mission and Vision Statements and Their Potential Impact on Employee Behavior and Attitudes: The Case of a Public but Profit-Oriented Tertiary Institution. International z Journal of Business and Social Science, 3(14), 15-26.

[18] Davis, G. \& Cobb, J. (2010). Resource dependence theory: Past and future. Bingley: Emerald Group Publishing Limited.

[19] Efendioglu, A.M., \& Karabulut, A.T. (2010). Impact of strategic planning on financial performance of companies in Turkey. International Journal of Business and Management, 5(4), 1-23

[20] Ganley, E. (2010). Strategic planning boosts morale, budget. Associated Press.

[21] Gharakhani, D., Rahmati, H., Farrokhi, M.R. \& Farahmandian, A. (2013). Total Quality Management and Organizational Performance. American Journal of Industrial Engineering, 1(3), 46-50.

[22] Goleman, D. (2010). What makes a leader? Harvard Business School Publishing Corporation Retrieved from www.hbr.org on 12/15/2014.

[23] Hadi, F.A., \& Adavi, P. (2016). The Barriers in Implementing TQM on Construction Projects in Iraq. Global Journal of Engineering Science and Research Management. 3(4), 2349-4506

[24] Hammar, M. (2017). Quality Management Systems. Retrieved from https://advisera.com/9001academy/

[25] Harrison, J.S. and Wicks, A.C. (2013). Stakeholder theory, value and firm performance. Business Ethics Quarterly, 23, 97-125

[26] Hill, C. \& Jones, G., (2012). Strategic management theory, An integrated approach. (10th ed.). Mason: Wiley India.

[27] Howe, J. (2011). Embedding the business continuity management programme within the corporate culture.

[28] Hucyynski, A., \& Buchanan, D. (2013). Organizational Behavior, (8th edition), Harlo: Pearson

[29] John, A.P., \& Richard, B.R. (2011). Strategic Management; Formulation, Implementation and Control (12th Edition). New York: McGraw Hill International Edition

[30] Juan, G. E., Daniel, J.J., \& Micaela, M. C. (2013). Organizational culture for total quality management. Journal of Total Quality Management \& Business Excellence. 24, 10.

[31] Jurevicius, O. (2013). McKinsey 7s Model. Strategic management insight.

[32] Karim, A.J. (2011). Business Disaster Preparedness: An Empirical Study for measuring the Factors of Business Continuity to face Business Disaster. International Journal of Business and Social Science, 2(18), 183 - 192.

[33] Kasongo, K., \& Moono M. (2010). Factors That Lead to a Successful TQM Implementation: A Case Study on the Zambian Tourism Industry

[34] Kheni, N.A., \& Ackon, F. (2015). Impact of Total Quality Management Practices (TQMPs) on Construction Project Quality Performance in Developing Countries: Study of Construction Businesses in Ghana. International Journal of Management Science, 2(3), 35-51.

[35] Kinyanjui, N. J \& Juma, D (2014). Investigate the effect of strategic plans implementation on performance in Kenya's public universities. A case study of the University of Nairobi. European Journal of Business Management, 2(1), 161-173.

[36] Kombo K. \& Tromp, A. (2011). Proposal and Thesis Writing: An introduction. Nairobi: Pauline Publications Africa

[37] Konzi, M.J. (2012). The Relationship between Strategic Plan Implementation and Performance of Manufacturing firms in Tanzania. MBA Thesis

[38] Kosgei, J.M. (2014). Challenges Facing the Implementation of Total Quality Management in Secondary Schools: A Case of Eldoret, East District, Kenya, Global Journal of Human Resource Management, 3(1), 12-18.

[39] Kothari, C.R. (2011). Research Methodology; Methods and Techniques. New Delhi: New Age International Publishers.

[40] Kreitner, R. \& Kinicki, A. (2010). Organizational Behavior. (9th ed.) New York: McGraw-Hill/Irwin

[41] Kuria, L, K., Namusonge, G, S., Iravo, M. (2016). Effect of Leadership on Organizational Performance in the Health Sector in Kenya. International Journal of Scientific and Research Publications, 6(7)

[42] Lincoln, Y.S., Lynham, S.A., \& Guba, E.G. (2011). Paradigmatic controversies, contradictions and emerging confluences. In N. K. Denzin, \& Y. S. Lincoln (eds.), The sage handbook of qualitative research (4th ed.), (pp. 97 - 128). Thousand Oaks, CA: Sage.

[43] Matata, D.J., \& Wafula, M.K. (2015). Effects of Quality Managemen Systems on Performance of Kenya Ports Authority. International Journal of Scientific and Research Publications, 5(5)

[44] Mbecke, M. (2014). A Primer on E-Government: Sectors, Stages, Opportunities, and Challenges of Online Governance. London: The Library of Congress

[45] Mugenda, O. M. \& Mugenda, A. (2009). Research methodology. (2nd Ed). Research Methods; Quantitative and Qualitative Approaches. Nairobi Acts Press.

[46] Mugenda, O.M \& Mugenda, A.G. (2013). Research Methods: Quantitative and Qualitative approaches, Nairobi: African center for technology studies, Pp.181-195

[47] Obonyo, P. \& Arasa R. (2012). The relationship between strategic planning and firm performance. International Journal of Humanities and Social Science Vol. 2 No. 2

[48] Odongo, M. \& Owuor D. (2015) Effects of Strategic Planning on Organizational Growth

(A Case Study of Kenya Medical Research Institute, Kemri). International Journal of Scientific and Research Publications, Vol. 5, Issue 9.

[49] OECD. (2013). Public Management Service, Public Management Committee. (5th ed.) New Delhi: Prentice- Hall of India Private Limited.

[50] Olesia W. S., Namusonge, G.S. \& Iravo, M.E. (2013). Role of Servant Leadership on Organizational Commitment: An Exploratory Survey of State Corporations in Kenya. International Journal of Humanities and Social Science, 3(13).

[51] Onyango, E.Y. (2012). Factors influencing the implementation of the Kenya sugar industry strategic plan (2010-2014). MBA Thesis. Kenyatta University.

[52] Oronsaye, S. (2010). Creating the Service Delivery of Our Dreams. Office of the Head of the Civil Service on the Federation, Federal Government of Nigeria.

[53] Oruma, B. W., Mironga, J, M., \& Muma, B. O. (2014). Top Management Commitment Towards Implementation of Total Quality Management (TQM) in Construction Companies in Nakuru County-Kenya. International Journal of Economics, Finance and Management Sciences, 2(6), 332-338. doi 10.11648/j.ijefm.20140206.15

[54] Oyedele, S. (2015): The Nigerian Public Service and Service Delivery under Civil Rule. Journal of Public Administration, Finance and Law, 2(1), 1-7.

[55] Rahimnia, F., Polychronakis, Y., \& Sharp, J.M., (2009). A conceptual framework of impeders of strategy implementation from an exploratory case study in an Iranian University: Contemporary Middle Eastern Issues. Vol.2 No.4, pp.246-261

[56] Rajasekar, D. J (2014). "Factors affecting effective strategy implementation in a service industry: A study of electricity distribution companies in the Sultanate of Oman.” International Journal of Business and Social Science, Vol. 5 No. 9

[57] Rothaermel, F., T (2012). Strategic management Concepts and cases, McGraw Hill Education, London.

[58] Sekaran, U. (2013). Research methods for business: A skill building approach (4th ed.). New York: John Wiley \& Sons, Inc. 
[59] Sekaran, U., \& Bougie, R. (2012). Research methods for business: A skill building approach (5th ed.). New York: John Wiley \& Sons, Inc

[60] Sharma, S. K., Gupta, S. G., \& Singh, R. (2014). Implementation of TQM for Improving Organizational effectiveness. International Journal of Application or Innovation in Engineering \& Management (IJAIEM), 3(9).

[61] Šukle, D. \& Stojan S. (2012). Strategic planning effectiveness comparative analysis of the Macedonian context. Economic and Business Review vol. 14 No. 12012 63-93

[62] Tamrakar, R. (2010). Impact of Citizen Charter in Service Delivery: A Case of District Administration Office. New Delhi: Kathmandu

[63] Thompson, A.A., Peteraf, M., Gamble, J.E., \& Strickland, A.J., (2012). Crafting and Executing Strategy: Concepts and Readings (18th Edition). New York: McGraw-Hill

[64] Wali, S., \& Boujelbene, Y. (2011). Cultural influences on TQM implementation and financial performance, 14, 30-45

[65] Wani, I.A., \& Mehraj, H.K. (2014). Total Quality Management in Education: An Analysis. International Journal of Humanities and Social Science Invention, 3, 71-78

[66] Wheelen, T. \& Hunger, D. (2012). Strategic management and business policy: Towards Global Sustainability. Boston: Pearson Education.
[67] Wickramasuriya, P., \& Dharmasiri, A. S. (2010). Factors Affecting the Implementation Effectiveness of ISO 9001 (2000) Standard and its Impact on Business Results. Sri Lankan Journal of Management, 15(2-4), 1-12.

[68] Wolfgang, G. (2010). Aquinas on management and its development, Journal of Management Development, 29(7/8), $706-715$.

[69] Yukl, G. \& Mahsud, R. (2010). Why flexible and adaptive leadership is essential. Consulting Psychology Journal: Practice and Research, 62(2), 8193. DOI: $10.1037 / \mathrm{a} 0019835$.

[70] Zahid, I. M., \& Khan, R. A. (2011). The Growing Concept and Uses of Training Needs Assessment: A Review with Proposed Model. Journal of European Industrial Training, 35(5), 439-466. 28 pp

[71] Zikmund, G.W., Babin, B.J., Carr, C.J., \& Griffin, M. (2010). Business research methods. (8th ed.). South-Western: Cengage Learning.

\section{AUTHORS}

First Author - Gahonzire, Y, Jomo Kenyatta University of Agriculture and Technology, gavhy6@yahoo.fr

Second Author - Mulyungi, M. P, Jomo Kenyatta University of Agriculture and Technology, Mwendandu2017@gmail.com 